Article

\title{
The Exilic Imperative of American Jewry
}

\author{
Michael S. Alexander
}

Department of Religious Studies, College of Humanities, Arts, and Social Sciences, University of California, Riverside, Riverside, CA 92521, USA; michael.alexander@ucr.edu

Received: 26 November 2018; Accepted: 10 December 2018; Published: 13 December 2018

\begin{abstract}
This article considers the existence of an exilic imperative in the historical and identity hermeneutics of American Jewry. Author considers cases of (1) American Jewish identification with racial outsiders, including the appropriation of historical, cultural, and religious forms; (2) the persistent creation of American Jewish ethnoburbs, unlike other white ethnic groups; and (3) the creation of exilic fantasy literature by American Jewish novelists. The author suggests that although American conditions do not justify interpretations of Jewish social alienation, American Jews have nevertheless applied traditional Jewish exilic hermeneutics to those American conditions.
\end{abstract}

Keywords: American Jewry; American Jewish history; identity; diaspora; exile; ethnicity; historiography; memory; demography; ethnoburb; literature; fiction; Jewish Question

\section{Introduction-The Phantom Jewish Question}

In American Jewry: A New History, Eli Lederhendler pauses the chronology to discuss a telling element of American Jewish memory and interpretation that has existed practically from the first moment of American settlement. American Jewish historiography has been fascinated with other diaspora communities, each with Golden Ages, which have come to violent ends, especially those of the Iberian, Slavic, and Germanic empires. In telling and retelling these lachrymose tales, American Jews seem to be wondering aloud whether violent destruction will be their fate as well.

Spain, Germany, and Russia represent more than just former homelands. Rather they have haunted American Jews in a way that is unparalleled by other American groups' folk memories. ... The cautionary tales of these Jewish Diasporas' rise, great promise, and calamitous demise cast a shadow over American Jews' sense of their own history, and endowed them with a mission peculiarly their own: to dodge history's bullet, to prove America to be the exception, to become the Jewish diaspora that 'made it,' and to inherit the mantle of all previous diasporas.

"The Euro-centric part of American Jewish history," Lederhendler concludes, "assumes a symbolic universe of meaning, rather than a prosaic tale of everyday affairs," (Lederhendler 2016). While many today may be less aware of former fascinations with Spanish Jewry, the specters of the Slavic and Germanic annihilations more obviously continue to constitute a foundation of identity for American Jews. In fact, these are so routinely invoked that I am not so sure they do not belong among the prosaic and everyday.

In these notes, I would like to address a curious aspect of this "haunting" and "shadow over American Jews' sense of their own history" — especially the imperative to "dodge history's bullet". Because no such bullet has even come close to striking the United States. Looking at the record of American Jewish history, there simply have been no similar existential threats, or even signs of the serious possibility of them. Rather, the overwhelming rate, quality, and kinds of acceptance of Jews in America-economic, social, political, cultural, religious, and even genetic (judging by rates of both 
intermarriage and conversion to Judaism)—all indicate that American Jews have enjoyed a veritable Platinum Age, even when compared to the Golden Ages of other diasporas. An exceptional American Jewish experience becomes even more obvious when Jews are compared to other American ethnic and racial groups, which have not all found the same plethora of acceptances or successes, to say the least.

I myself realized the error of my own lachrymose impressions only in graduate school, when I read Deborah Dash Moore's truly radical work At Home in America (Moore 1981). Since that time, historians have confirmed for the general course of American Jewish history what Moore first noticed about the generation coming up in the 1920s-the acceptance of Jews into all realms of American life, public and private, has been far more thorough than in any other diaspora; is nearly indistinguishable from the low hurdles faced by other white ethnic minorities; and in the Jewish case, has typically been achieved in the very first generation after each wave of immigration. Moore's study of the Jewish generation of the American 1920s, as well as Beth Wenger's sequel study of the 1930s, are particularly telling in their descriptions of American successes, because these decades coincided with the gravest retreat to nationalism in the country's history (Wenger 1996).

There is no bullet. This certainly poses a problem for the relevance of Iberian, Slavic, or Germanic history for American experiences. But the problem, I think, runs deeper. The exceptional case of American acceptance confounds the central myth of Jewish historiography itself, stated succinctly by Arnold Eisen in his book dedicated to the subject, "In the beginning, there was exile." Exile and return (and always back to exile once again) has comprised the hermeneutic lens for understanding all streams of Jewish history in all of the founding narratives. It structures Genesis, Exodus, and the Deuteronomist history. This exilic principle then arranges all subsequent Jewish historiographical attempts, including the later biblical writings; the historical reckonings of the Talmud and Midrash; the snippets of history one finds in the medieval biblical interpretation; the cosmic histories of the Kabbalah; and then, once again, the dedicated historiographical writings, which emerged in the sixteenth century and continue in our day (Eisen 1986).

Exile and return, over and again; through the centuries, Jews have believed this lens applicable to their lives, because it makes sense of the conditions of political and social alienation where Jewish life has existed for the predominant portion of its history. Anywhere there has been a serious articulation of the Jewish Question, the lens of exile has made sense. Even in the relative security of Golden Age Iberian, Germanic, and Slavic experiences, there always existed some serious form of this Jewish Question. By serious, I mean that practical and often official questions existed about the rectitude of Jews to be physically present. These were not hypothetical questions. What are the limits of Jewish belonging? How total is Jewish acceptance? Do Jews really belong among us at all? Even in those Golden ages, such questions were serious and immediate, not speculative. So long as these questions were serious, there could be serious recourse to the concept of exile for organizing the Jewish history of that place.

But at least since the time Peter Stuyvesant's Jewish Question was answered so succinctly by the investors of the Dutch West India Company, who can claim seriousness for the Jewish Question in America? George Washington's letter to the Newport Synagogue clarified America's federal position, and has never been seriously contested, except locally (in housing and job discrimination), and temporarily (mostly during the 1920s and 1930s). Even the most forceful poser of the Jewish Question in American history, Henry Ford, speaking in the very midst of America's "tribal twenties", could speak only hypothetically, and was quickly forced to apologize for even asking (Dinnerstein 1994; Baldwin 2001; Higham 1988).

So, in an America without a serious Jewish Question, there has been no bullet of history to dodge. Nevertheless, Lederhedler is absolutely right. There is a haunting. While American Jewish experiences themselves cannot coherently be understood from the perspective of exile and alienation, favorable American circumstances and facts have not stopped American Jews from trying to make the old story fit, at times by any means necessary. In the arena of memory, this shoehorning has often taken the form of identifying with European history (typically in the demise of Golden Ages outlined by Lederhendler), 
or with Israeli history (in the form of its embattlement). These decidedly foreign narratives provide the exilic frame by which American Jews understand themselves. The Jewish Questions of those foreign places are transplanted to America, and act as a kind of phantom. This phantom Jewish Question, like Hamlet's father, is perceptible to no one except American Jews themselves. Yet it organizes the whole telling of the tale.

The phantom Jewish Question does not merely foreground the bullets of European and Israeli Jewish struggles. It animates a larger and even stranger set of everyday happenings among the prosaic moments of Jewish American life. Here, I would like to notice just three. These examples are not comprehensive, but rather indicate a phenomenon that I hope readers may themselves extrapolate to understand other mystifying areas of American Jewish identity, namely: (1) like no other white ethnic group, American Jews display widespread appropriation of the cultural and religious practices of burdened outsider groups in America (typically those of color), and identify with histories of American marginalization not their own; (2) like no other white ethnic group, American Jews create and re-create ethnoburbs for themselves, utilizing and reproducing historical markers to earlier periods of ghetto settlement; and (3) exceedingly popular American Jewish novelists have taken to writing counter-histories_-fantasies really_in which a serious Jewish Question is transposed to American shores. These several arenas of historical fascination and exilic interpretation make little sense, I think, except to fulfill an exilic imperative of memory and identity among Jewish Americans.

\section{Discussion}

\subsection{Appropriation}

Scholars have now long noticed the tendency for American Jews to identify with the history of their country's marginalized groups, especially with those racially marginalized (in America, typically people of color). Hasia Diner first documented the case of widespread Jewish identification with African-American history in her landmark book, In the Almost Promised Land, the very title of which embodied the easy and common fusion in the Yiddish press of African-American history with Jewish exilic identity (Diner 1977). One will search other newspapers of white ethnics of the period to find very little discourse of this kind, especially regarding a "shared sense of history" so often touted in the Jewish press. Some readers may know that I followed Diner's lead by exploring a cultural site of such American Jewish identification, the music industry, where Jews very comfortably took African-American cultural forms as (somehow) representative of their own experiences, again typically invoking the specific language of Exile to justify the appropriation. As Jews came to understand African Americans as America's exiled people, the place of American Jews in their own sacred history came into question. Identification and appropriation, then, seems to have helped Jews maintain an exilic identity in America (Alexander 2001).

Recently, scholars have explored similar identifications of Jews with different American peoples of color, especially in the religious realm, with the twentieth and twenty-first century phenomena of Jewish Buddhists ("Ju-Bus" as they have been named) and Jewish Hindus ("Ju-Hus"). American Jews often take on (self-anointed) roles as spokespeople of American Buddhist and Hindu religious communities. The American Jewish fascination with Buddhism is well known (Cadge 2004; Wilson 2014; Braun 2013; Sigalow 2018), so here I will mention some Hindu cases, from Radhanath Swami (formerly Richard Slavin) as a formidable leader within the International Society for Krishna Consciousness, to Baba Ram Dass (formerly Richard Alpert) and his classic book, Be Here Now (Dass 1971), to Krishna Das (born Jeffrey Kagel) and the many Jewish leaders in the kirtan (spiritual music) scene. Stark and Bainbridge demonstrate a significant representation of Jews in ISKCON (The International Society for Krishna Consciousness), Ananda, and the Satchidananda Ashram (Stark and Bainbridge 1985). While Jews comprised approximately 3\% of the United States population in 1974, that same year $14.5 \%$ of the family affiliation of members of the Hare Krishna movement were Jewish (Judah 1974). In the early 1980s, a full 20\% of the residents of Bhagvan Rajneesh's (Osho's) 
ashram were Jewish (Altglas 2014). As a contemporary example, Sridhar (née Steven) Silberfein, the founder and organizer of the annual Bhakti Fest in Joshua Tree since 2009, likely the largest annual gathering of Hindu practices in North America, is a white Jew from Long Island (Spense 2013). Are these religious appropriations of people of color so different from the cultural appropriations once performed by $\mathrm{Al}$ Jolson in blackface? Others are beginning to note a similarity of appropriation patterns (Lucia 2014; Palmer and Siegler 2017; Wilson 2014).

Finally, David Koffman in his fascinating forthcoming book, The Jews' Indian, has seen this phenomenon in American Jewish interest in Native American life. This was especially apparent in the nineteenth century, but continued well into the twentieth and perhaps continues even now. The fascination appears to have been initiated among those Jews who headed west and served the mercantile and distribution needs of the American frontier. Reports from these merchants quickly filtered through to the general Jewish press, in articles demonstrating a decided understanding of the Native American story with Jewish exilic language. Koffman also demonstrates that the Jews of the nineteenth century themselves were acutely aware of the tension of identifying with marginalized peoples, while at the same time doing the colonial work of an empire that was destroying those peoples (Koffman 2019).

Pointedly, many others along with Koffman have also now observed that historical and cultural interest in marginalized minorities generally entails the appropriation of "everything but the burden" (Tate 2003). An identity of marginality can be achieved through identification with minority histories and cultures, yet without taking on the social limitations that continue to burden those marginalized American groups. Since the sixties and to today, this is now achieved by many Americans, not just Jews; indeed, at this point, the phenomenon may well be worldwide. However, that American Jews have been a vanguard of these kinds of identity appropriations, so early on and in so many diverse realms, is not really subject to debate. It may bear mentioning that American Jewish scholars themselves have been foundational in the disciplines of African American studies, Asian religions, and Native American studies, especially in the earliest expressions of these fields in American universities, before marginalized representatives themselves found legitimacy to hold those positions. These Jewish scholars have sometimes noticed the tension of that awkward situation (Doniger 1994; Doniger 2014).

How to explain this widespread Jewish fascination with the cultures and travails of outsider groups, taking on all but their burdens? I think an exilic imperative plays a part. The facts of American Jewish history do not allow Jews to play themselves as the exiled protagonists of the American story; therefore, they have appropriated the identities of groups more convincingly appropriate for that role, typically taking on everything but their burden.

\subsection{The Persistent Ethnoburb}

Demographer Bruce Phillips has recently revealed a unique and nearly inexplicable characteristic of American Jewish geography. Unlike other white ethnic groups-but strikingly similar to Asian Americans-American Jews continue to self-ghettoize into "ethnoburbs." This continues to happen over a half century after the end of restriction covenants, which themselves were never profoundly limiting for American Jews (especially when compared to debilitating restrictions on groups of color). No other groups in America, except those of color, continue to build and then reconstitute ethnoburbs. Deborah Dash Moore discussed ethnic areas of Jewish "second settlement" in the 1920s, as Jews entered the middle class and left their initial ghetto communities, and other white ethnics also created similar second-settlement areas (Moore 1981). But Phillips is talking about third, fourth, and sometimes fifth areas of ethnic reconstitution. White groups do not typically do this, except white Jews. Why do Jewish Americans replicate ethnic settlement over and again, and act more like Chinese, Korean, and Thai people, than the Italians, Irish, and Polish who came to America from Europe at about the same time as those Jews? (Phillips 2016).

I would only supplement Phillips's profound insight with elements of Jewish geographical memory that have been discussed by historians of American Jewry. Hasia Diner in Lower East Side 
Memories recorded a rather straightforward nostalgia for New York's tenement area (and era) of first settlement, of course justified with exilic language of longing for home (Diner 2000). Other white ethnic groups hold similar nostalgia for locations of their first American settlements (i.e., the Little Italy of so many cities). But who then continues to hold identity ties to areas of second and third settlement, even as they reconstitute themselves in fourth and fifth locations?

According to Lila Corwin Berman, the Jews of Detroit did. At the very moment the Jews of Detroit enacted a white flight from metropolitan downtown and created third-settlement ethnoburbs, simultaneously, they composed a new language of a special "Jewish" connection to the very urban spaces they were abandoning. Berman has noted "the soul-searching testimony of Jewish leaders and average folks trying to understand why their neighborhoods in the late 1940s or early 1950s stopped feeling Jewish" (Berman 2014; Berman 2015). But why such soul searching and lamentation over their own upward mobility?

The Michigan Jews were not alone to feel both lamentation and continued identity connection among fleeing metropolitan Jews; at different times, New York, Philadelphia, Miami, Chicago, and Los Angeles have all supported this unique Jewish discourse of longing. For all hand wringing and proclamations of continued solidarity with urban locations and populations, Jews typically moved out of "changing" neighborhoods, but continued along with identity connections to those places—of course from safer distances. Like those who appropriate "everything but the burden", post-metropolitan Jews did not themselves submit to forfeiture of privilege, even as they convinced themselves that they had not really forsaken their old neighborhoods and neighbors. The discourse of their continued metropolitanism, even after their white flight, expressed the belief that they left only involuntarily, and were themselves victims of displacement, as though the pogroms of Fiddler on the Roof had forced these moves, and not their own shirking of the concrete racial burdens concomitant with deciding to stay.

What can account for a group identity that voluntarily repeats its physical separation, over and again, into ethnoburb after ethnoburb, while it marks movements of upward mobility with the language of involuntary expulsion and longing for the old home? What kind of myth supports the building up of an ideal about each and every place one has left, location after location and generation after generation? What narrative can turn Jews into the impoverished protagonists of their own white flight? I hope the storyline of exile is beginning to seem significant in the organization of American Jewish geography.

\section{3. "But What If?—Exilic Fantasy}

My final example comes from counter-historiographical writings, so labeled because the exiles depicted therein are not claimed actually to have occurred. These are strictly figments of the novelist's imagination, hypothetical scenarios. They ask the following: But what if the Jewish Question were to be asked in America? But what if American Jews were actually in exile, and did not even know it? This thought experiment, I think, reveals a foundation of American Jewish identity, and the popularity of the novels I am about to describe may attest to this. I am speaking of Philip Roth's The Plot Against America (Roth 2004) and Michael Chabon's The Yiddish Policemen's Union (Chabon 2007). I will discuss these together, and briefly, because by now, the reader should be expert in spotting the imposition of foreign lenses over American details.

In the case of these two novels, as the corroborating historical facts that might support Jewish alienation in America could not be found, the authors chose to invent those facts. In Roth's novel, history becomes counter-history in 1940, when Charles Lindbergh (who in reality was a Nazi sympathizer) runs against Franklin Roosevelt in the American presidential election and wins. Thus, Nazi Germany makes a non-aggression pact with America, much as it had with Spain, and America begins to relocate its Jews into internment camps. This is perfect scare copy for Jews, an American concentration camp. Of course, it did not happen, but what if? The brilliance of Roth's counter-history is that although the story is fantastic, it is not entirely so. Lindbergh 
was indeed enormously popular; real American anti-semitism and isolationism indeed had almost prevented America from entering the war. Nevertheless, Roth's scenario is still fantastic. No American concentration camps held Jews. Such camps held Japanese, but not Jews.

Michael Chabon's "but what if?" ventures into outright fabrication. I almost do not call it counter-history, his is indeed an exile fantasy. His story begins in the prologue to the War, the 1930s, during which time the American government decides not so much to loosen its borders for Jewish refugees (which historically it never did), but rather to create a reservation for two million of them in Alaska. The reservation is Yiddish speaking, and it is self-governable for sixty years, at which time the property will return to the United States and the Jews will be scattered with the four winds. During that time, fledgling Israel loses its war for independence in 1948, and so, the Alaska Reservation becomes the sole home for the world's displaced population of Jewry. Just like in Russia, it is an American Pale of Settlement, a perfect American exile fantasy.

So, although American Jews were never rounded up and put in concentration camps or corralled into Alaskan reservations, perhaps these things could have happened-but what if it had happened!- and this possibility alone is quite enough to titillate with fear, to revive the Jewish sense of alienation, and to re-affirm the continued significance of the principle of exile, even for American Jewry. In this way, they restate the Jewish Question for Americans, although they must invent circumstances to do so.

That is to say, these fantasies confirm the feeling of American Jewish memory, if not the facts of that memory. They are able to achieve this because they corroborate not what Jewish history is, but what it is supposed to be. Perhaps there is a specifically Jewish muse of history, a Yiddishe Clio whom Hesiod forgot to mention. And exile is what the Yiddishe Clio demands of the action. She whispers an exilic imperative. If Jews themselves are not quite in exile, says the Yiddishe Clio, they must create the fantasy of one. And these American novelists have gone and done just that. I submit to the reader that a great deal of American Jewish literature, both counter-factual and factual, is simply inexplicable if one does not consider the fantasy of alienation that often so animates such works.

\section{Conclusion-Exclusiveness and Tolerance in America}

Jewish identity seems to require American Jews to remember, reenact, and sometimes invent conditions of exile. Finding the phenomenon in America should not be totally surprising. Jacob Katz published his magisterial study of Jewish self-alienation and the propagation of "self-conscious distinctiveness" over a half-century ago, Exclusiveness and Tolerance. There, he discovered an imperative of exilic identity so strong that even in the medieval period, when one would think Jewish exclusion from Christendom to have been axiomatic, even then, Jewish identity often became threatened by perceived social integration. When that happened, Jewry worked hard to re-inscribe the founding myth of Jewish distinction, typically by creating onerous new religious rituals and legal restrictions to achieve this. Thus, Jewish communities revitalized their distinctiveness from time to time, to halt integration, and so to continue to mark themselves as a people apart. Later, when modernity, liberalism, and emancipation finally forced Jews "to clarify their attitude towards their country and fellow citizens", Katz concludes, "they found less difficulty in achieving tolerance towards Christians than in justifying their adherence to Judaism" (Katz 1961).

Tolerance gained, and exile undone, what justifies adherence to Judaism? What grounds Jewish ethnic identity?

Katz realized of course that in Europe, tolerance was never actually gained; it was only offered conditionally, and even then, de jure, but rarely de facto. That the Jewish Question was even asked in seriousness by liberal leaders (such as Napoleon in his pointed questions to the Assembly of Jewish Notables), and then repeatedly had to be qualified and reframed, indicates the fundamental difference of European liberal political thought from American. Granted, liberalizing America had related questions, but not about Jews; the political status of Africans was the subject of vital debate, as was 
Chinese exclusion, Native American assimilability, Japanese patriotism, and the contours of the Latino border, but never the Jewish Question, except as it has been asked by Jews themselves.

So, I think a phantom Jewish Question haunts American Jewish identity, propels even its prosaic behaviors, and shapes its memory. Indeed, how much of American Jewish life simply makes no sense without a Yiddishe Clio whispering an exilic imperative? But perhaps I misconstrue what others may take to be harder evidence of serious American exclusions. Or perhaps hard evidence is simply not yet above the surface of history and ready to be seen. Of course, these scenarios are possible. The power of myth is in its perpetual possibility. In those cases, I am then terribly wrong, and the Jewish Question in America is no phantom. Only time will tell. For now, however, I am more bothered by the fantasies, appropriations, and very questionable moral justifications, than I am afraid of any forced demise of American Jewry or Jewish identity. Insofar as there is any mechanism of decay, I see impertinence and irrelevance, not exclusion; and for the culprit, I see nothing but ourselves.

Funding: This research received no external funding.

Acknowledgments: I would like to thank Jon Butler and the organizers of his retirement conference where I first presented some of these ideas. Lila Corwin Berman commented incisively on an early draft of this article. Amanda J. Lucia generously directed me to references regarding Buddhism and Hinduism. Finally, I would like to thank Eli Lederhendler, my teacher over the course of decades.

Conflicts of Interest: The authors declare no conflict of interest.

\section{References}

Alexander, Michael. 2001. Jazz Age Jewws. Princeton: Princeton University Press. ISBN 0691086796.

Altglas, Veronique. 2014. From Yoga to Kabbalah: Religious Exoticism and the Logics of Bricolage. New York: Oxford University Press, p. 50. ISBN 0199997632.

Baldwin, Neil. 2001. Henry Ford and the Jews: The Mass Production of Hate. New York: PublicAffairs. ISBN 1891620525.

Berman, Lila Corwin. 2014. The Death and Life of Jewish Neighborhoods. Bangkok: Shma. Available online: http:/ / shma.com/2014/06/the-death-and-life-of-jewish-neighborhoods/ (accessed on 25 June 2018).

Berman, Lila Corwin. 2015. Metropolitan Jews: Politics, Race, and Religion in Postwar Detroit. Chicago: University of Chicago Press. ISBN 022624783X, 978-0226247830.

Braun, Erik. 2013. The Birth of Insight: Meditation, Modern Buddhism, and the Burmese Monk Ledi Sayadaw. Chicago: University of Chicago Press, pp. 162-69. ISBN 022641857X.

Cadge, Wendy. 2004. Heartwood: The First Generation of Theravada Buddhism in America. Chicago: The University of Chicago Press, pp. 164-70. ISBN 0226089002.

Chabon, Michael. 2007. The Yiddish Policemen's Union: A Novel. New York: Harper/Collins. ISBN 0007149824.

Dass, Ram. 1971. Be Here Now. Taos: Lama Foundation. ISBN 0517543052.

Diner, Hasia. 1977. In the Almost Promised Land: American Jews and Blacks, 1915-1935. Westport: Praeger Publishers. ISBN 0837194008.

Diner, Hasia. 2000. Lower East Side Memories: A Jewish Place in America. Princeton: Princeton University Press. ISBN 0691007470.

Dinnerstein, Leonard. 1994. Anti-Semitism in America. New York: Oxford University Press. ISBN 0195037804.

Doniger, Wendy. 1994. The Love and Hate of Hinduism. In Between Jerusalem and Benaras: Comparative Studies in Judaism and Hinduism. Edited by Hananya Goodman. Albany: SUNY Press, pp. 15-22. ISBN 0791417166.

Doniger, Wendy. 2014. Banned in Bangalore. New York Times. March 5. Available online: https:/ /www.nytimes. com/2014/03/06/opinion/banned-in-bangalore.html?_r=0 (accessed on 25 June 2018).

Eisen, Arnold. 1986. Galut: Modern Jewish Reflection on Homelessness and Homecoming. Bloomington: Indiana University Press. ISBN 0253325501.

Higham, John. 1988. Strangers in the Land: Patterns of American Nativism, 1860-1925, 2nd ed. New Brunswick: Rutgers University Press, pp. 264-99. ISBN 0813513170.

Judah, J. Stillson. 1974. Hare Krishna and the Counterculture. New York: John Wiley and Sons, p. 147. ISBN 0471452009.

Katz, Jacob. 1961. Exclusiveness and Tolerance: Studies in Jewish-Gentile Relations in Medieval and Modern Times. New York: Berman House, pp. ix-xv, 182-96. ISBN 0874413656. 
Koffman, David. 2019. The Jews' Indian: Colonialism, Pluralism, and Belonging in America, 1860s-1960s. New Brunswick: Rutgers University Press. ISBN 197880086X.

Lederhendler, Eli. 2016. American Jewry: A New History. Cambridge: Cambridge University Press, pp. $190-247$. ISBN 0521196086.

Lucia, Amanda. 2014. Reflections of Amma: Devotees in a Global Embrace. Berkeley: University of California Press. ISBN 0520281144.

Moore, Deborah Dash. 1981. At Home in America: Second Generation New York Jews. New York: Columbia University Press. ISBN 0231050623.

Palmer, David, and Elijah Siegler. 2017. Dream Trippers: Global Daoism and the Predicament of Modern Spirituality. Chicago: University of Chicago Press. ISBN 022648484X.

Phillips, Bruce. 2016. Not Quite White: The Emergence of Jewish 'Ethnoburbs' in Los Angeles 1920-2010. American Jewish History 100: 73-104. [CrossRef]

Roth, Philip. 2004. The Plot Against America. New York: Houghton Mifflin. ISBN 0618509283.

Sigalow, Emily. 2018. Breaking Down the Barriers: The Encounter between Judaism and Buddhism in the Late Nineteenth Century. American Jewish History 102: 459-80. [CrossRef]

Spense, Rebecca. 2013. Sridhar Silberfein's Long, Strange Trip from N.Y. Jew to Hindu Honcho. New York: Jewish Telegraphic Agency, Available online: https:/ /www.jta.org/2013/05/21/life-religion/sridhar-silberfeinslong-strange-trip-from-n-y-jew-to-hindu-honcho (accessed on 25 June 2018).

Stark, Rodney, and William S. Bainbridge. 1985. The Future of Religion: Secularization, Revival and Cult Formation. Berkeley: University of California Press, pp. 400-1. ISBN 0520057317.

Tate, Greg, ed. 2003. Everything but the Burden: What White People Are Taking from Black Culture. New York: Broadway Books. ISBN 076791497X.

Wenger, Beth. 1996. New York Jews and Great Depression: Uncertain Promise. New Haven: Yale University Press. ISBN 0300062656.

Wilson, Jeff. 2014. Mindful America: The Mutual Transformation of Buddhist Meditation and American Culture. New York: Oxford University Press, pp. 43-74. ISBN 0199827818.

(C) 2018 by the author. Licensee MDPI, Basel, Switzerland. This article is an open access article distributed under the terms and conditions of the Creative Commons Attribution (CC BY) license (http:/ / creativecommons.org/licenses/by/4.0/). 